\title{
Consideration of Programs and Operations of Farms Providing Agro-Healing Service
}

\author{
Sang Mi Lee, Na Ra Jeong ${ }^{*}$, Seon Hee Jeong, Gyung Mee Gim, Kyung Sook Han, Young Chea, Kwang Jin Kim, \\ and Hyun Jin Jang
}

Urban Agriculture Research Division, National Institute of Horticultural and Herbal Science, Rural Development Administration, Wanju 55365, Korea

\begin{abstract}
This study was designed to examine agro-healing services and programs provided and operated by farms in Korea. The results of the analysis of the agro-healing programs and operation of farms were as follows. The purpose of the operation of farms was to raise productivity by managing farms in a cooperative way through agricultural production, education and healing, and to raise income by processing and selling agricultural products. It was difficult to access farms by public transport and thus visitors had to use their own cars. The size of farms varied. The main resources utilized in the surveyed programs were plants, rural environments and landscapes, and agricultural products. The programs were conducted using resources that were commonly found in rural areas. Facilities on each farm were equipped with facilities (indoor and outdoor learning place, gardens, vegetable gardens, orchards, etc.) and convenience facilities (parking lots, drinking fountains, kiosks, etc.) to support program operation. However, facilities for the handicapped and accommodation facilities were insufficient. The programs operated on each farm utilized agricultural resources, farm produce, and rural resources and were classified into activities such as making, feeling, and growing. The average number of people who operated the family-centered program was 2-3, having qualifications such as welfare horticultural therapists, forest interpreters, experience instructors, and social workers. In addition, they had expertise in medicinal food, dietary life, and social welfare, and they also had essential expertise required to operate programs.
\end{abstract}

Keywords: agricultural products, care farming, healing program, social farming, vitalization of agriculture

\section{Introduction}

As people's interest in improvement in the quality of life and health grows, their interest in healing programs from a social aspect has also increased to deal with conflicts, stress and increasing welfare costs caused by a variety of social problems in modern society. Following these changes, agro-healing has emerged as a new trend in the agricultural area. European countries including Netherlands and Belgium use similar terms such as farming for health, green care and social farming, and they have long been trying to heal participants' mental and physical scars and to expand the responsibility and network of farms. Moreover, it has been reported to spread positive perceptions of agriculture and to have positive

This study was supported by the Joint Research Program of the Rural Development Administration (PJ011266022017).

Received: December 5, 2018, Revised: December 23, 2018, Accepted: January 16, 2019

First author: Sang Mi Lee, E-mail: sangmilee@korea.kr, ORCID: 0000-0003-1049-4705

*Corresponding author: Na Ra Jeong, E-mail: jnr202@korea.kr, ORCID: 0000-0002-0235-1424 
economic effects in local communities and countries (Hine et al., 2008). Under the green care umbrella classified by Sempik et al. (2010), agro-healing areas can be divided into social and therapeutic horticulture; animal assisted intervention; care farming; facilitated green exercise as treatment; ecotherapy; and wilderness therapy (nature therapy).

In Japan, the concept is understood, under the name of agriculture-welfare cooperation (農福連繫), as welfare agriculture that provides a base for those with intellectual or physical disabilities to participate in agricultural activities and stand on their own feet and for the elderly to participate in farming activities suitable for them for their independence and health (Kawate, 2015).

Agro-healing in Korea is defined as a "project that recover, maintain and promote the health of people through healing services that utilize agricultural or rural resources, or products (Lee et al., 2016)." It is to achieve healing effects through agricultural activities or natural environments in rural areas or exchanges among people. Agro-healing utilizes natural and social environments in agricultural and rural areas as a healing element in order to pursue the healthy lives of individuals or groups. From the aspect of healing, the role of health care, social rehabilitation, education and employment is included (Sempik et al., 2010). That is, agricultural activities, natural environments or atmospheres in rural villages and exchanges among people through events in rural areas give ordinary people relaxation and comfort and also give chances to recover to those who need healing (Kang and Kim, 2017).

Agro-healing in Korea is still in an early stage, and thus it is necessary to develop operation models for healing farms that can be applied to agricultural environments in Korea and healing programs that can be introduced in order to ensure agro-healing settles and is activated early on. In particular, the demand for support for the integrated operation of and programs for healing farms with operators of rural education farms certified by the Rural Development Administration has increased, and requests for the introduction of agro-healing programs have also been received from existing farms for experience education (Lee et al., 2016).

In Korea, studies on various topics have been conducted from the aspect of resources including horticultural therapy (Cho, 2013; Kwak, 2015; Kim, 2017), animal-assisted therapy (Park and Kim, 2012; Kim, 2013; Her and Hong, 2013; Cho and Lee, 2014; Jung, 2015), forest healing (Jeong and Ahn, 2015a, 2015b, 2016), healing garden (Ahn, 2015, 2016), and food healing (Park, 2014), and basic studies have been also conducted focusing on directions in the development of agro-healing and related policies, contents and cases (Lee, 2013; Gim, 2013; Lee et al., 2016; Jeong, 2017). However, the development of operation models and programs for healing farms has not been much studied.

To meet the increasing demand for the development of these programs, this study aimed to survey and analyze healing farms that provided agro-healing services and programs in Korea, and to provide basic information for developing operation models and programs in the future.

\section{Research Methods}

\section{Research sites}

This study targeted farms that claimed to provide agro-healing services in order to survey and analyze the general characteristics of the operation of farms and operated programs from July to November 2016. Target farms were selected in this study among those that were operating agro-healing programs and were recommended by agricultural technology centers in local communities and in each city and province. A total of 17 farms were recommended, and they were reviewed through written and on-site surveys by a total of 6 experts including 2 junior agricultural researchers, 2 senior agricultural researchers, 1 agricultural extension agent and 1 consultant. For written surveys, each target farm submitted written documents on the purpose of the operation of agro-healing services, programs, utilized facilities (equipment), the 
operational status of services, incomes, visions, etc. Based on the submitted documents, preliminary surveys were carried out on the suitability of utilized resources, creative utilization, the status of utilized facilities, target-customized programs, the existence of manuals, the appropriateness of operation, customer management, administration and public relations, healing effects and mutual cooperation with local communities. After that, on-site surveys were performed to confirm them. Based on the results, a total of 11 farms that were found to provided proper agro-healing services were selected as final target sites (Table 1).

\section{Survey and analysis methods}

Surveys were conducted based on written documents and on-site reviews from July to November 2016, and the general operational status of each farm, resources, and programs that the farms were operating were surveyed.

The general status of farms was surveyed as follows: the purpose of farm operation (agricultural production, education, healing, processing \& sales), accessibility to farms and the size of farms. The resources of farms surveyed in this study were divided into utilized resources, facility resources and human resources. The programs operated by farms were surveyed as follows: the number of programs, resources for activities (agricultural resources/rural resources/products), the content of activities (growing/making/feeling), types of industries (primary/secondary/tertiary/sixth industry), and human resources for the operation of programs (Table 2).

\section{Analysis methods}

The frequency of each farm and the total frequency of farms were analyzed based on the surveyed results, and multiple answers were allowed for some questions, which was reflected in the frequency analysis.

\section{Results and Discussion}

\section{General status}

\section{Purpose of farm operation}

The purpose of the operation of farms that provided agro-healing services was surveyed, and healing (11 farms) was the

Table 1. List and location of surveyed farms

\begin{tabular}{cl}
\hline Case & \multicolumn{1}{c}{ Location } \\
\hline A & Gangsang-myeon, Yangpyeong-gun, Gyeonggi-do \\
B & Osong-eup, Heungdeok-gu, Cheongju-si, Chungbuk \\
C & Janggok-myeon, Hongseong-gun, Chungnam \\
D & Gochang-eup, Gochang-gun, Jeonbuk \\
E & Gamcheon-myeon, Yecheon-gun, Gyeongbuk \\
F & Jain-myeon, Gyeongsan-si, Gyeongbuk \\
G & Sanyang-eup, Tongyeong-si, Gyeongnam \\
H & Dong-myeon, Yangsan-si, Gyeongnam \\
I & Bugok-myeon, Changnyeong-gun, Gyeongnam \\
J & Geumji-myeon, Namwon-si, Jeonbuk \\
K & Gurye-eup, Gurye-gun, Jeonnam \\
\hline
\end{tabular}


highest, followed by agricultural production ( 9 farms), education ( 9 farms) and processing and sales ( 2 farms), which indicated that many farms focused on healing that has been highlighted recently (Table 3). However, only one farm focused solely on healing, while most farms, based on agricultural production, additionally aimed at education, healing and processing and sales simultaneously. That is, they were seeking for solutions to raise incomes and create non-farm incomes, and as an effort to do so, they seemed to operate programs that can attract consumers and increase profits.

In particular, Farm B focused on education and healing instead of agricultural production in order to provide psychological counseling and horticultural therapy for urban citizens unlike other farms. Farm D was found to focus on process and sell eco-friendly agricultural products produced in its local community, while Farm G developed, produced and distributed phytoncide products using cypress trees, and provided experience programs. Farm $\mathrm{K}$ answered that it was operated solely for healing, and was operated with the aim of taking care of people's health (飲食養生) focusing on the medicinal properties and functions of locally-produced agricultural products based on the principle that medicines and foods have the same origin (藥食洞源).

\section{Accessibility to farms}

Accessibility to farms was analyzed, and there were 2 farms accessible by public transport including those located in

Table 2. Farm survey contents

\begin{tabular}{|c|c|c|}
\hline Classification & & Investigation contents \\
\hline \multirow{3}{*}{ General status } & Purpose of farm operation & Agricultural production, education, healing, processing and sales \\
\hline & Farm access & Accessible by public transportation \\
\hline & Farm size & Area, number of farm animals \\
\hline \multirow{3}{*}{ Resource } & Utilized resources & Plants, animals, processing farm produce, farm work, rural environment/landscape \\
\hline & Facility resources & Facilities on farm \\
\hline & Human resources & Full-time, part-time employment \\
\hline \multirow{5}{*}{$\begin{array}{l}\text { Operational } \\
\text { program }\end{array}$} & Number of programs & \\
\hline & Activity resources & Agricultural/rural/products \\
\hline & Activity contents & Growing/making/feeling activities \\
\hline & Types of industries & Primary/secondary/tertiary/sixth industry \\
\hline & Man power & Human resources in program operation \\
\hline
\end{tabular}

Table 3. Purpose of farm operation

\begin{tabular}{|c|c|c|c|c|c|c|c|c|c|c|c|c|}
\hline \multirow{2}{*}{ Classification } & \multicolumn{11}{|c|}{ Case } & \multirow{2}{*}{ Total } \\
\hline & A & $\mathrm{B}$ & $\mathrm{C}$ & $\mathrm{D}$ & $\mathrm{E}$ & $\mathrm{F}$ & $\mathrm{G}$ & $\mathrm{H}$ & I & $\mathbf{J}$ & $\mathrm{K}$ & \\
\hline Agricultural production & $\circ$ & & $\circ$ & $\circ$ & $\circ$ & $\circ$ & $\circ$ & $\circ$ & $\circ$ & $\circ$ & & 9 \\
\hline Education & $\circ$ & $\circ$ & & $\circ$ & $\circ$ & $\circ$ & $\circ$ & $\circ$ & $\circ$ & $\circ$ & & 9 \\
\hline Healing & $\circ$ & $\circ$ & $\circ$ & $\circ$ & $\circ$ & $\circ$ & $\circ$ & $\circ$ & $\circ$ & $\circ$ & $\circ$ & 11 \\
\hline Processing/sales & & & & ० & & & $\circ$ & & & & & 2 \\
\hline
\end{tabular}


Yanpyeong, Gyeonggi, and Osong, Chungbuk. It was inconvenient for people to use their own car to access the rest 9 farms (Table 4). As this shows, since most farms were located in rural areas and focused on agricultural production at the same time, there were limitations to access those farms by public transport. Therefore, in order to improve the convenience of urban citizens in using agro-healing programs, they need to improve accessibility through various measures such as securing their own means of transportation, connecting them with locally available public transport and providing call services. From the perspective of consumers, no matter how beautiful natural landscapes healing farms have, if they are located far from where consumers are, the use rate of healing farms will inevitably decrease. Therefore, accessibility is an important factor that needs to be considered when providing agro-healing services for urban residents who need physical and mental healing in healing farms (Kim and Ha, 2018).

\section{Size of farms}

The average size of farms was 7,332 $\mathrm{m}^{2}$ (maximum: $20,460 \mathrm{~m}^{2}$, minimum: $1,800 \mathrm{~m}^{2}$ ). In the case of livestock farms, the size of farms is often estimated based on livestock numbers. In this study, there were 3 farms that utilized animals, but only one farm raised livestocks and provided a learning experience program connected with school education under the theme of hares, raising 500 rabbits (Table 5).

As shown above, the size of farms varied, and, in fact, their size is an important factor in operating healing farms. However, the bigger the farms, the more labor forces need to be secured and the higher the intensity of labor. Therefore, it is necessary to maintain the proper size of farms in which essential facilities can be established to support operating programs, but additional studies need to be conducted on the essential facilities and the size of farms required for agro-healing in the future.

\section{Resources of farms}

\section{Utilized resources}

Resources utilized in programs were analyzed, and plants were found to be the most widely utilized resource (28.9\%), followed by rural environments and landscapes (23.7\%) and processed agricultural products (21.1\%) (Table 6), which was similar to the results of Gim et al. (2013). Considering that agro-healing provides healing services that utilize agricultural or rural resources, or products, many programs were found to utilize plants produced through agricultural activities, and

Table 4. Access to farms by public transport

\begin{tabular}{|c|c|c|c|c|c|c|c|c|c|c|c|c|}
\hline \multirow{2}{*}{ Classification } & \multicolumn{11}{|c|}{ Case } & \multirow{2}{*}{ Total } \\
\hline & $\mathrm{A}$ & B & $\mathrm{C}$ & $\mathrm{D}$ & $\mathrm{E}$ & $\mathrm{F}$ & G & $\mathrm{H}$ & $\mathrm{I}$ & $\mathrm{J}$ & $\mathrm{K}$ & \\
\hline Use of public transport & $\circ$ & $\circ$ & & & & & & & & & & 2 \\
\hline Difficulty with public transport & & & $\circ$ & $\circ$ & $\circ$ & $\circ$ & $\circ$ & $\circ$ & $\circ$ & $\circ$ & $\circ$ & 9 \\
\hline
\end{tabular}

Table 5. The area of the farm and the number of livestock raised on the farm

\begin{tabular}{|c|c|c|c|c|c|c|c|c|c|c|c|}
\hline \multirow{2}{*}{ Classification } & \multicolumn{11}{|c|}{ Case } \\
\hline & A & $\mathrm{B}$ & $\mathrm{C}$ & $\mathrm{D}$ & $\mathrm{E}$ & $\mathrm{F}$ & $\mathrm{G}$ & $\mathrm{H}$ & I & $\mathrm{J}$ & $\mathrm{K}$ \\
\hline Area $\left(\mathrm{m}^{2}\right)$ & 6,100 & 3,960 & 3,640 & 3,300 & 10,000 & 1,800 & 13,200 & 6,300 & 5,800 & 6,100 & 20,460 \\
\hline Number of livestock & & & & & & & & & 500 & & \\
\hline
\end{tabular}


Table 6. Resources used by the operating program

\begin{tabular}{|c|c|c|c|c|c|c|c|c|c|c|c|c|}
\hline \multirow{2}{*}{ Classification } & \multicolumn{11}{|c|}{ Case } & \multirow{2}{*}{ Total } \\
\hline & $\mathrm{A}$ & $\mathrm{B}$ & $\mathrm{C}$ & $\mathrm{D}$ & $\mathrm{E}$ & $\mathrm{F}$ & $\mathrm{G}$ & $\mathrm{H}$ & I & $\mathrm{J}$ & $\mathrm{K}$ & \\
\hline Plants & $\circ$ & ० & ० & ० & $\circ$ & ○ & $\circ$ & ० & ○ & $\circ$ & ० & $11(28.9 \%)$ \\
\hline Animals & ० & & & & ○ & & & & ○ & & & $3(7.9 \%)$ \\
\hline Agricultural production & $\circ$ & & & ० & $\circ$ & ० & ○ & & $\circ$ & $\circ$ & ० & $8(21.1 \%)$ \\
\hline Farm work & $\circ$ & $\circ$ & ० & & $\circ$ & ० & & & $\circ$ & $\circ$ & & $7(18.4 \%)$ \\
\hline Rural environment/landscape & ० & $\circ$ & & & ० & $\circ$ & $\circ$ & ० & ○ & ० & o & $9(23.7 \%)$ \\
\hline Sum & 5 & 3 & 2 & 2 & 5 & 4 & 3 & 2 & 5 & 4 & 3 & $38(100 \%)$ \\
\hline
\end{tabular}

rural resources such as environments and landscapes (mountains, rivers, fields, etc.). In particular, plants were utilized on all the surveyed farms, and rural landscapes and environments were also utilized as a basic resource. These resources, however, are commonly seen in rural areas. It is difficult to generalize them, but instead unique resources only seen in rural areas and their unique regional characteristics need to be reflected. In addition, there were only three farms where animals were utilized, which indicated that most programs or facilities have some limitations as they were similar to those provided by existing experience farms that utilize plants and rural landscapes. Therefore, in order to ensure the introduction of agro-healing contributes to increasing profit sources for farms in the future, it is necessary to develop and distribute various programs that consumers want to experience and can be utilized in rural areas (Gim et al., 2013). In particular, resources should not be limited to plants, but instead animals and various resources need to be utilized together. Programs that have healing effects need to be developed by continuously integrating a wide range of resources and academic fields.

\section{Facility resources}

Facilities owned by farms were analyzed, and the share of facilities for program operation was the highest (46.2\%), followed by convenience facilities (27.6\%), other facilities (22.1\%), facilities for the handicapped (2.8\%), and accommodation facilities (1.4\%), which indicated that there were very few facilities for the handicapped and accommodations (Table 7). If the purpose of healing farms is not only to provide programs for the general public, but also to be utilized for the rehabilitation and independence of special groups such as those with physical and mental disabilities and the elderly, facilities for the special groups need to be expanded.

Facilities for program operation included indoor and outdoor experience areas, and gardens, greenhouses and vegetable gardens for experiences, which seems to be related to the high share of plant-based programs (Figure 1). Meanwhile, facilities on each farm showed different characteristics depending on the characteristics of programs operated by each farm. Farms that utilized cypress trees as the main resource installed facilities where people can directly experience phytoncide such as foot bathtubs, air cafe and trails. In terms of convenience facilities, parking lots were installed on most of the surveyed farms, and other basic amenities such as drinking fountains, toilets and sinks were also provided. In terms of facilities for the handicapped, a wheelchair ramp was installed on one farm, and three farms had gardens accessible by wheelchair users. Other facilities such as gardens (landscape enjoyment) and lawns were created on most farms. However, it was difficult to find safety-related facilities, although safety is the second most valued factor by consumers following accessibility (Kim and Ha, 2018). Therefore, operators of healing farms need to make sure essential safety equipment and emergency medical facilities are installed in their agricultural facilities for healing. 
Table 7. Facilities built on the farm

\begin{tabular}{|c|c|c|c|c|c|c|c|c|c|c|c|c|c|}
\hline & \multirow{2}{*}{ Classification } & \multicolumn{11}{|c|}{ Case } & \multirow{2}{*}{ Total } \\
\hline & & $\mathrm{A}$ & $\mathrm{B}$ & $\mathrm{C}$ & $\mathrm{D}$ & $\mathrm{E}$ & $\mathrm{F}$ & $\mathrm{G}$ & $\mathrm{H}$ & $\mathrm{I}$ & $\mathrm{J}$ & $\mathrm{K}$ & \\
\hline \multirow{16}{*}{$\begin{array}{l}\text { Program } \\
\text { operation } \\
\text { facilities }\end{array}$} & Mini concert hall & & & & & & & o & & & & & 1 \\
\hline & Handcraft workshop & & & & & & & & & $\circ$ & & & 1 \\
\hline & Orchard & & & & & & & & & & & $\circ$ & 1 \\
\hline & Air cafe & & & & & & & 0 & & & & & 1 \\
\hline & Tea house & & & & & & & & & & $\circ$ & & 1 \\
\hline & Breeding farm & $\circ$ & & & & $\circ$ & & & & ० & & & 3 \\
\hline & Promenade & & & ० & & & & ○ & & ० & $\circ$ & & 4 \\
\hline & Dietary experience place & & & & & & & & & ० & & & 1 \\
\hline & Indoor learning place & $\circ$ & $\circ$ & $\circ$ & $\circ$ & $\circ$ & $\circ$ & ० & $\circ$ & ० & ○ & $\circ$ & 11 \\
\hline & Outdoor learning place & $\circ$ & & ० & $\circ$ & $\circ$ & $\circ$ & ० & $\circ$ & ० & $\circ$ & & 9 \\
\hline & Tea plantation & & & & & & & & & & 0 & & 1 \\
\hline & Green house & $\circ$ & $\circ$ & ० & $\circ$ & $\circ$ & $\circ$ & ० & $\circ$ & & & & 8 \\
\hline & Raising seedling facilities & & $\circ$ & ० & $\circ$ & & & ० & $\circ$ & & & & 5 \\
\hline & Experience garden & $\circ$ & $\circ$ & 0 & $\circ$ & $\circ$ & $\circ$ & ० & $\circ$ & ० & ० & $\circ$ & 11 \\
\hline & Vegetable garden & $\circ$ & & & $\circ$ & $\circ$ & $\circ$ & & $\circ$ & ० & 0 & & 7 \\
\hline & Sub total & 6 & 4 & 6 & 6 & 6 & 5 & 8 & 6 & 8 & 7 & 3 & $65(45.8 \%)$ \\
\hline \multirow{12}{*}{$\begin{array}{l}\text { Convenience } \\
\text { facilities }\end{array}$} & Cafe & & & & $\circ$ & $\circ$ & & & & & & & 2 \\
\hline & Playground & & & & & & & ० & & & ० & & 2 \\
\hline & Cafeteria & & & & $\circ$ & & & 0 & $\circ$ & & & & 3 \\
\hline & Deck terrace & & & & & & & & & $\circ$ & & & 1 \\
\hline & Rest facilities & & $\circ$ & & $\circ$ & & & $\circ$ & $\circ$ & & & & 4 \\
\hline & Sink & & $\circ$ & & & & $\circ$ & & & $\circ$ & 0 & & 4 \\
\hline & Drinking fountain & & $\circ$ & & $\circ$ & & $\circ$ & & $\circ$ & $\circ$ & 0 & & 6 \\
\hline & Parking lot & $\circ$ & $\circ$ & ० & $\circ$ & $\circ$ & $\circ$ & ० & $\circ$ & $\circ$ & & $\circ$ & 10 \\
\hline & Weight room & & & & & & & & & $\circ$ & & & 1 \\
\hline & Restroom & & $\circ$ & & & & & 0 & & $\circ$ & $\circ$ & & 4 \\
\hline & Rest area & $\circ$ & & & & $\circ$ & & & & & & & 2 \\
\hline & Sub total & 2 & 5 & 1 & 5 & 3 & 3 & 5 & 4 & 6 & 4 & 1 & $39(27.5 \%)$ \\
\hline \multirow{3}{*}{$\begin{array}{l}\text { Facilities for } \\
\text { the disabled }\end{array}$} & Raised bed & $\circ$ & & & & $\circ$ & & & $\circ$ & & & & 3 \\
\hline & Ramp & & & & & & & ० & & & & & 1 \\
\hline & Sub total & 1 & 0 & 0 & 0 & 1 & 0 & 1 & 1 & 0 & 0 & 0 & $4(2.8 \%)$ \\
\hline \multirow{6}{*}{$\begin{array}{l}\text { Other } \\
\text { facilities }\end{array}$} & Sign board & & $\circ$ & ० & & & $\circ$ & & $\circ$ & & 0 & $\circ$ & 6 \\
\hline & Fermentation place & & & & & & & & & & & $\circ$ & 1 \\
\hline & Compost place & $\circ$ & $\circ$ & ० & & ० & $\circ$ & & & $\circ$ & & & 6 \\
\hline & Appreciation garden & $\circ$ & $\circ$ & 0 & $\circ$ & ० & $\circ$ & 0 & $\circ$ & $\circ$ & 0 & ० & 11 \\
\hline & Lawn & $\circ$ & & O & $\circ$ & ० & & ० & $\circ$ & & 0 & ० & 8 \\
\hline & Sub total & 3 & 3 & 4 & 2 & 3 & 3 & 2 & 3 & 2 & 3 & 4 & $32(22.5 \%)$ \\
\hline \multirow{3}{*}{$\begin{array}{l}\text { Accommodatic } \\
\text { facilities }\end{array}$} & & & & & & & & & & & ० & $\circ$ & 2 \\
\hline & Sub total & & & & & & & & & & 1 & 1 & $2(1.4 \%)$ \\
\hline & Total & 12 & 12 & 11 & 13 & 13 & 11 & 16 & 14 & 16 & 15 & 9 & 142 \\
\hline
\end{tabular}




\section{Human resources}

There were at least 1 and up to 6 workers who operated farms including part-time workers, and most farms were operated by owner couple or their family members. Those who had professional abilities required to operate programs accounted for $79 \%$ of the entire workers who operated farms on average (Table 8 ).
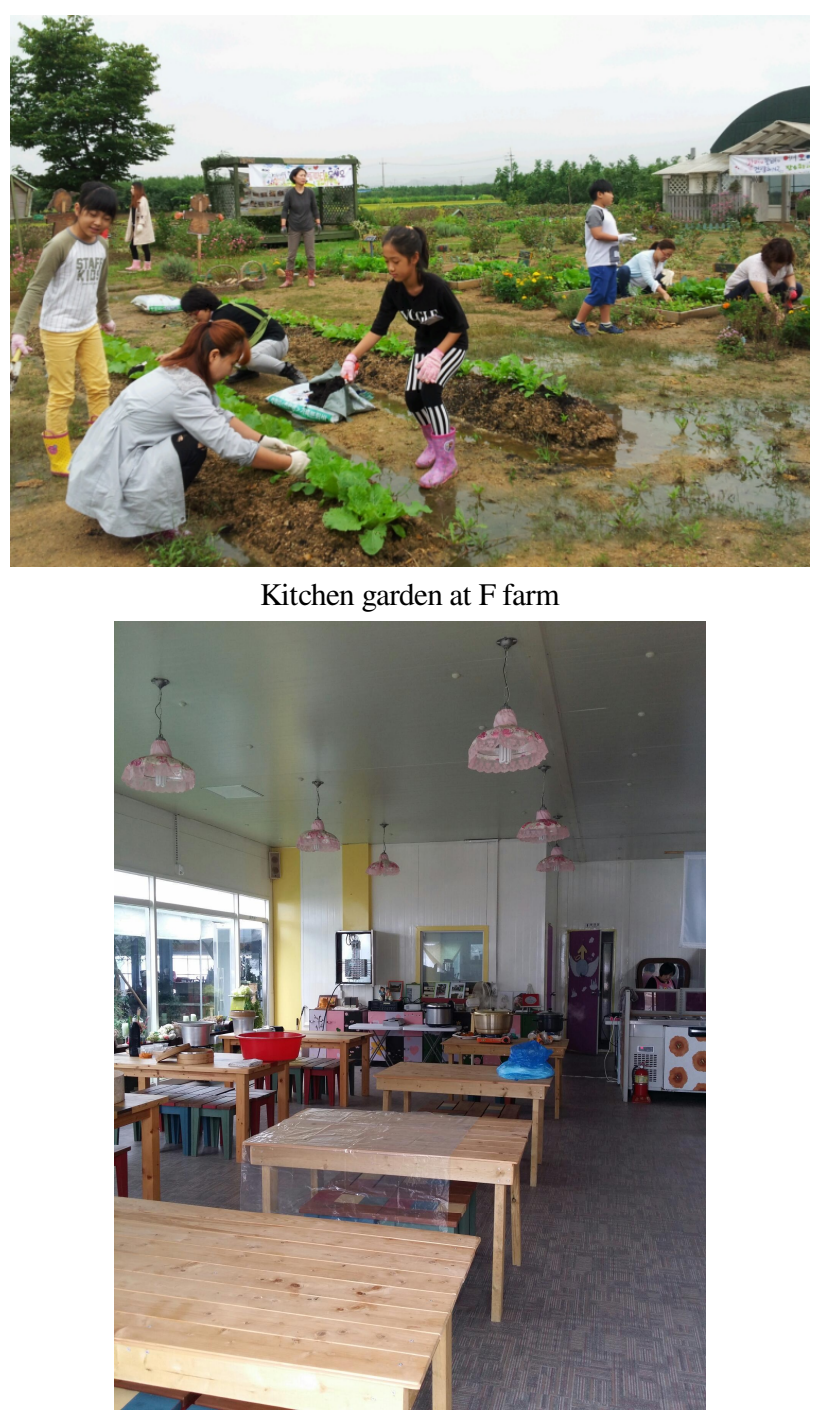

Interior learning center at D farm

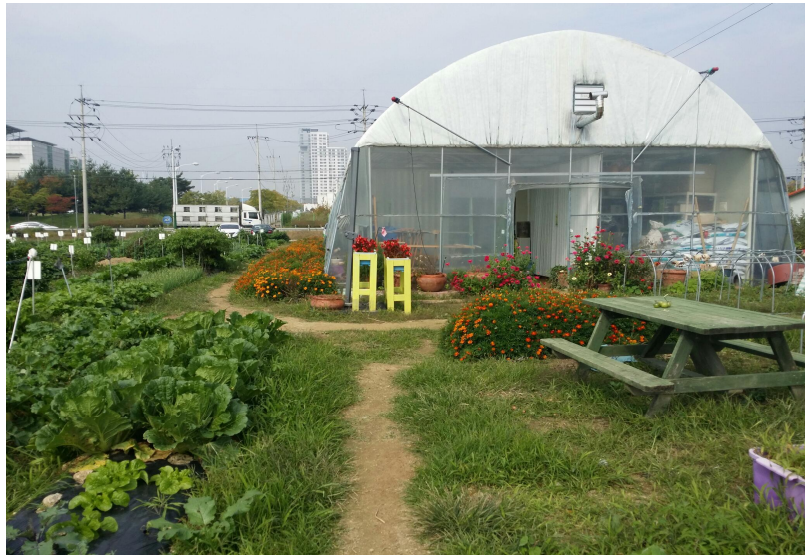

Greenhouse in B farm

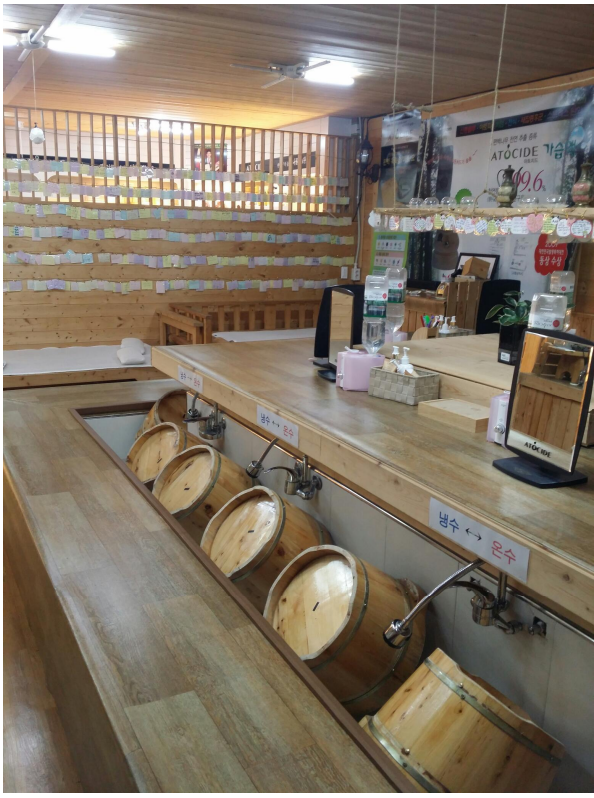

Foot baths in $\mathrm{G}$ farm

Figure 1. Examples of farm facilities.

Table 8. Manpower and expertise running the program

\begin{tabular}{|c|c|c|c|c|c|c|c|c|c|c|c|}
\hline \multirow{2}{*}{ Classification } & \multicolumn{11}{|c|}{ Case } \\
\hline & A & B & $\mathrm{C}$ & $\mathrm{D}$ & E & $\mathrm{F}$ & G & $\mathrm{H}$ & I & $\mathrm{J}$ & K \\
\hline Staff & 1 & 3 & 5 & 4 & 2 & 4 & 4 & 3 & 2 & 3 & 3 \\
\hline $\begin{array}{l}\text { Professionals running } \\
\text { programs }(\%)\end{array}$ & $\begin{array}{c}1 \\
(100)\end{array}$ & $\begin{array}{c}3 \\
(100)\end{array}$ & $\begin{array}{c}4 \\
(80)\end{array}$ & $\begin{array}{c}2 \\
(50)\end{array}$ & $\begin{array}{c}2 \\
(100)\end{array}$ & $\begin{array}{c}3 \\
(75)\end{array}$ & $\begin{array}{c}4 \\
(100)\end{array}$ & $\begin{array}{c}2 \\
(67)\end{array}$ & $\begin{array}{c}2 \\
(100)\end{array}$ & $\begin{array}{c}2 \\
(67)\end{array}$ & $\begin{array}{c}1 \\
(33)\end{array}$ \\
\hline
\end{tabular}




\section{Status of operated programs}

The number of programs operated by each farm was on average 7 (min. 3, max. 13), and the surveyed programs were analyzed by dividing them into resources for activities, the content of activities, types of industries and human resources for operation as follows.

\section{Resources for activities classified into agricultural resources/rural resources/products}

Resources for agro-healing activities (Figure 2) can be divided as follows: agricultural products and activities of cultivating agricultural products; animals (aquatic animals excluded) and activities of raising animals; forest products and agricultural resources required to cultivate and care forest products; natural environments that reflect the genuine identify of rural areas and have recreational, aesthetic, ecological and economic values; tangible and intangible resources such as natural landscape, products, history and culture and communities and rural resources that utilize them; agricultural products produced by agricultural activities (processed agricultural products, fishery products and foods made from fishery products excluded); and every food made from agricultural products or products that utilize them (Lee et al., 2016).

Out of the surveyed programs, 26 programs utilized agricultural resources, 22 programs utilized products, and 13 programs utilized rural resources (Table 9). Farm $\mathrm{G}$ operated a program to experience phytoncide released from cypress trees, and since cypress trees are not agricultural products, the program was classified into one that utilized forests, one of the rural resources.

\section{Content of activities classified into growing/making/feeling}

The content of agro-healing activities can be divided as follows: growing activities (cultivation) including sowing, cutting, replanting, cultivation, harvesting, watering, fertilization, aquaculture and gardening; making activities including flower arrangement, bouquets and baskets, corsages, wreaths, table decorations, garlands (festoons), grass dolls, topiaries, dish gardens, terrariums, pressed flower decorations, herbal soaps, potpourri pouches, cooking and decorating with them (or using them); and feeling activities (appreciation) including field trips, walking, collecting, drinking tea and talking (Lee et al., 2009).

Programs surveyed in this study were divided into activity types, and the number of making activities was the highest (24), followed by feeling activities (20) and growing activities (17) (Table 9). Making activities included making foods

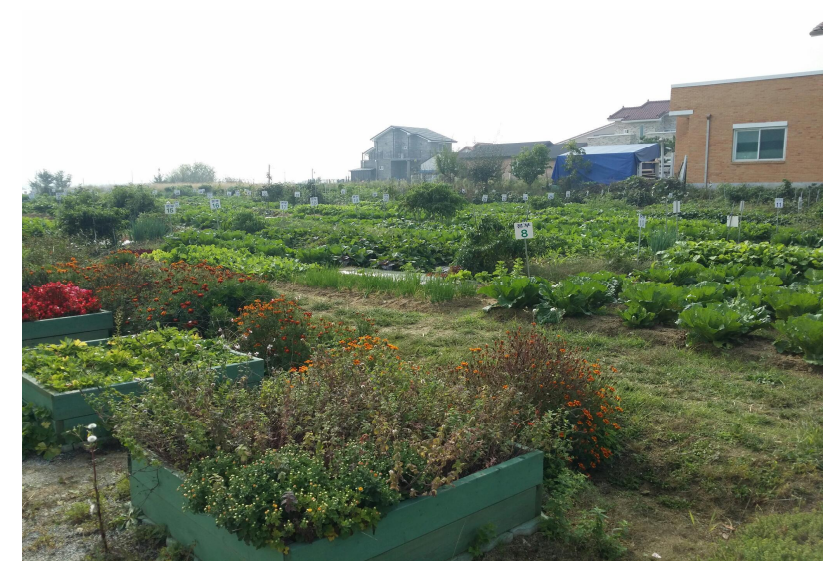

Activity resources of B farm

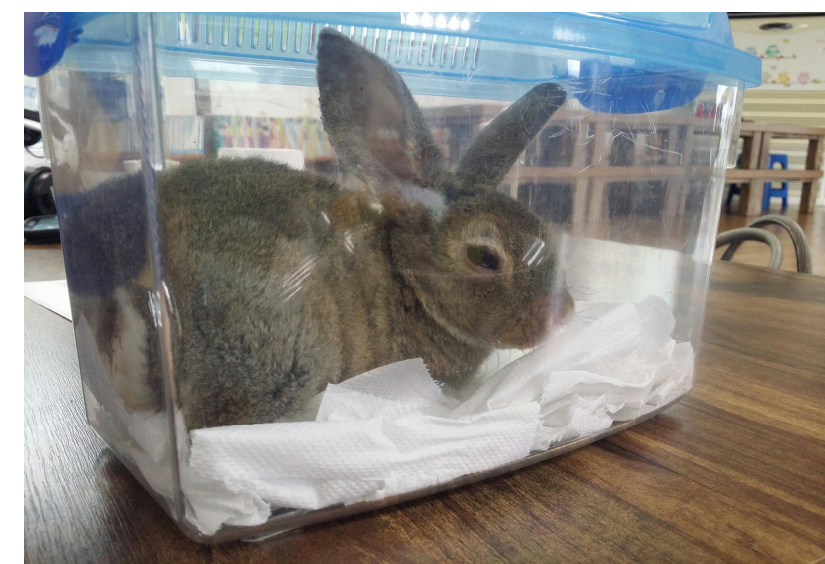

Activity resources of I farm

Figure 2. Example of activity resources for a program. 
Table 9. Number of programs operated by resource type on farm

\begin{tabular}{|c|c|c|c|c|c|c|c|c|c|c|c|c|c|}
\hline \multirow{2}{*}{ Classification } & & \multicolumn{11}{|c|}{ Case } & \multirow{2}{*}{ Tota } \\
\hline & & A & B & $\mathrm{C}$ & $\mathrm{D}$ & $\mathrm{E}$ & $\mathrm{F}$ & G & $\mathrm{H}$ & I & $\mathrm{J}$ & K & \\
\hline Program total & & 6 & 7 & 10 & 13 & 11 & 6 & 7 & 6 & 3 & 5 & 5 & 79 \\
\hline \multirow{4}{*}{ Resources } & Agricultural resources & 3 & 2 & 1 & 4 & 5 & 3 & & 2 & 2 & 2 & 2 & 26 \\
\hline & Rural resources & & 1 & & 1 & & & 7 & 1 & & 2 & 1 & 13 \\
\hline & Agricultural products & 2 & & 3 & 6 & 4 & 2 & & 2 & & 1 & 2 & 22 \\
\hline & Unclassified & 1 & 4 & 6 & 2 & 2 & 1 & & 1 & 1 & & & 18 \\
\hline \multirow{4}{*}{ Contents } & Growing activity & 3 & 2 & 1 & 1 & 3 & 3 & & 1 & 2 & & 1 & 17 \\
\hline & Making activity & & 1 & & 4 & 1 & & 7 & 1 & & 4 & 2 & 20 \\
\hline & Feeling activity & 2 & & 3 & 6 & 5 & 2 & & 3 & & 1 & 2 & 24 \\
\hline & Unclassified & 1 & 4 & 6 & 2 & 2 & 1 & & 1 & 1 & & & 18 \\
\hline \multirow{5}{*}{ Industries } & Primary industry & 3 & 3 & 1 & 2 & 4 & 3 & & 1 & 2 & 2 & 2 & 23 \\
\hline & Secondary industry & 2 & & 3 & 6 & 4 & 2 & & 3 & & 1 & 2 & 23 \\
\hline & Tertiary industry & & & 2 & 1 & 2 & & 7 & & 1 & 2 & 1 & 16 \\
\hline & Sixth industry & & 1 & & 2 & & & & 1 & & & & 4 \\
\hline & Unclassified & 1 & 3 & 4 & 2 & 1 & 1 & & 1 & & & & 13 \\
\hline
\end{tabular}

such as tea, beverage, jam and rice cake, woodworking, and making flower blocks. Participants in most of the programs utilized products or directly made products, or felt rural environments or landscapes, participating in agriculture.

\section{Types of industries classified into primary/secondary/tertiary/sixth industry}

The types of industries related to agro-healing can be classified into primary industries based on agricultural production, secondary industries that produce or process agricultural products, tertiary (service) industries, and senary industries that combine primary, secondary and tertiary industries all together (Lee et al., 2016).

Programs surveyed in this study were divided into industry types as follows: 23 primary industries, 23 secondary industries, 16 tertiary industries and 4 sixth industries (Table 9). The results indicated that most programs simply focused on agricultural production and processing, while there were only few programs that provided services or combined different industries (senary industries). Therefore, it will be necessary to develop programs of senary industries that embrace production, processing and services all together as agro-healing contents.

Resources for activities and types of activities were analyzed together, and the number of growing activities that utilized agricultural resources was the highest (17), followed by feeling activities (6) and making activities (3), which indicated that most agricultural resources were connected with growing activities (Table 10). That is, most of the surveyed programs mainly focused on activities such as growing or harvesting plants or caring animals. Rural resources were mostly connected with feeling activities such as walking in environments that release anions, foot bath with sun-dried salt water, drinking tea, meditation in forest, and observing resources in surrounding environments. Products were mostly connected with feeling and making activities that make jam, tea, rice cake and handmade fruit tea, utilizing products.

Resources for activities and types of industries were analyzed together, and agricultural resources were mostly utilized as a primary industry, while rural resources were utilized as a tertiary or senary industry. Products were mostly utilized as 
a secondary industry. These results indicated that the industry types of programs were determined depending on the characteristics of resources for activities (Table 11). As these results show, most programs were operated in a simple form such as producing or processing agricultural resources, and therefore, it will be necessary to develop programs that combine multiple resources.

It is also necessary to develop programs that can achieve other purposes such as developing individuals' potential abilities to address problems or meet demand of those who need healing, valuing labor forces and technological development, providing peaceful environments, maintaining friendly atmospheres in families and local communities and enjoying physical freedom, beyond resources for activities or types of industries (Loue, 2016).

\section{Human resources for the operation of programs}

As mentioned on human resources above, those who had professional abilities required to operate programs accounted for $79 \%$ of the entire workers. One of the most important factors in improving programs operated by farms and their quality is workers for the operation of programs (Lee et al., 2016), and most of the workers on the surveyed farms were found to have professional knowledge for operating programs.

Their abilities to operate programs were analyzed by area and were found to be related to healing and interpretation. Workers in the majority of the surveyed farms were found to have abilities to directly develop and operate programs such as welfare horticultural therapist Grade I or II, forest interpreter, humor therapist and experience instructor. Some had food or cooking-related professional abilities such as Korean food craftsman cook, dietary life instructor and barista. There were also social workers and those who majored in social welfare, and there was a farm operated by a psychiatrist (Table 12). As these results showed, those who operated the surveyed programs were found to complete educational courses related to the operation of programs, or to acquire qualifications with professionalism.

Once agro-healing is activated in the near future, it will be necessary to consider education programs that can improve farm operators' professional abilities and cooperation programs that can support professional workers due to difficulties in

Table 10. Program classification by farm resources and activity type

\begin{tabular}{|c|c|c|c|c|c|}
\hline Classification & Raising & Experience & Making & Unclassified & Total \\
\hline Agricultural resources & 17 & 6 & 3 & & 26 \\
\hline Rural resources & & 13 & & & 13 \\
\hline Agricultural products & & 1 & 21 & & 22 \\
\hline Unclassified & & & & 18 & 18 \\
\hline Sum & 17 & 20 & 24 & 18 & 79 \\
\hline
\end{tabular}

Table 11. Program classification by farm resources and industry type

\begin{tabular}{|c|c|c|c|c|c|c|}
\hline Classification & Primary industry & Secondary industry & Tertiary industry & Sixth industry & Unclassified & Total \\
\hline Agricultural resources & 19 & 3 & 4 & & & 26 \\
\hline Rural resources & 1 & & 9 & 3 & & 13 \\
\hline Agricultural products & 1 & 20 & & 1 & & 22 \\
\hline Unclassified & 2 & & 3 & & 13 & 18 \\
\hline Sum & 23 & 23 & 16 & 4 & 13 & 79 \\
\hline
\end{tabular}


Table 12. The professional skills of the person who runs the program

\begin{tabular}{ll}
\hline Classification & \multicolumn{1}{c}{ Ability } \\
\hline Social welfare & $\begin{array}{l}\text { Social worker, diploma of social work } \\
\text { Barista, instructor of dietary life, speciality of medicinal dish, baker, speciality of herbalism, } \\
\text { craftsman cook (Korean food) }\end{array}$ \\
Therapy/interpretation & $\begin{array}{l}\text { Exercise instructor for the elderly, experience instructor at rural, horticultural therapist (L1), horticultural } \\
\text { therapist (L2), forest interpreter, aroma therapist, laughter therapist, diploma of horticultural therapy, } \\
\text { experience instructor }\end{array}$ \\
Others & Psychiatrist, agriculturalist, speciality of tea culture, speciality of painting \\
\hline
\end{tabular}

obtaining these professional qualifications within a short period of time. In the United States, almost every healing farm operates their own program to train therapists and assistant therapists. In particular, students in local colleges who prepare to become an occupational therapist participate in healing farms in local communities as a trainee or an apprentice or a volunteer, which indicated that educational organizations in local communities are actively engaged in such programs and courses (Park and Kang, 2017). From this perspective, it will be also necessary to consider ways to enhance program operators' competence not only through special courses for agro-healing experts but also through cooperation between related academic fields and occupations.

\section{Conclusion}

The purposes of farm operation were mostly agricultural production, processing and sales, education and healing, and they were found to attempt to increase incomes by processing and sales agricultural products along with production activities. In terms of accessibility to farms, since there were limitations to access them by public transport, people had to use their own cars. In order to improve the convenience of people in visiting healing farms and increase their participation, accessibility needs to be improved through various ways such as securing their own means of transportation, providing information on locally available public transport and connecting with call services. The size of farms varied, but it is recommended to maintain the proper size of farms in which essential facilities can be established to support operating programs.

The most widely utilized resource in agro-healing was found to be plants, followed by rural environments and landscapes, and processed agricultural products, while animals were relatively less utilized. However, agro-healing resources need to reflect the unique characteristics of rural areas and their regional characteristics, and animals and multiple resources need to be utilized without being limited to plants. Each farm had facilities required to support operating programs such as indoor and outdoor classrooms, gardens, vegetable gardens and orchards, and convenience facilities such as parking lots, rest rooms and cafeteria. However, there were only few farms that had facilities for the handicapped and accommodations. If the purpose of agro-healing is not only to provide programs for the general public, but also to support the rehabilitation and independence of special groups such as the handicapped, people with mental disabilities and the elderly, it will be necessary to expand facilities to support them, and to install essential safety equipment and emergency medical facilities.

Each farm was found to operate 7 programs on average, and agricultural resources, and products and rural resources were utilized. These utilized resources were divided into making, feeling and growing activities. In terms of types of 
industries, most programs only focused on primary and secondary industries with production and processing activities, and, thus, it is necessary to develop programs of senary industries that embrace production, processing and services together as agro-healing contents.

Programs on healing farms were operated by 2-3 family members on average. Operators had professional qualifications such as welfare horticultural therapist, forest interpreter and experience instructor, and some had other specialized areas such as medicinal herbal foods, dietary life instructor and social welfare, which indicated that they had enough professional skills and knowledge for operating actual programs. However, it will be still necessary to promote agro-healing and to consider ways to enhance farm operators' professional abilities and to foster and support professional workers.

This study targeted 11 farms that claimed to provide agro-healing services, and their general status were analyzed with frequency analysis. It was difficult to generalize their results, and there were also some limitations such as lack of comparison with overseas cases. Therefore, in order to meet the increasing expectation of agro-healing on actual rural education farms and experience farms, it will be necessary to analyze and benchmark exemplary overseas cases, to suggest ways to secure facilities and safety according to each farm's characteristics and types, and to research and develop programs and profit-creation models for each target in follow-up studies.

\section{References}

Ahn, D.S. 2015. Analyses on sound effects for soundscape design of healing garden at psychiatric hospitals - Focused psychological and physiological effects -. J. Korean Inst. Landsc. Archit. 43(1):82-95.

DOI:10.9715/KILA.2015.43.1.082

Ahn, D.S. 2016. Analyses of Schizophrenics' physiological reaction and visual preference for green spaces. J. East Asian Landsc. Stud. 10(2):1-16. Retrieved from https://landscape.jbnu.ac.kr

Cho, J.H. 2013. Analysis of horticultural therapist education system in America and Korea. Master's thesis, Korea University, Seoul, Korea.

Cho, Y.M. and D.Y. Lee. 2014. Exploring consideration on the effect integrative recreation riding program of children in welfare facilities have on the increase of sociality: Focusing on the case of welfare facility Gangneung Jabiwon's children. J. Early Child. Educ. Educ. Welf. 18(1):6-29.

Gim, G.M. 2013. Strategic long term planning of green care based on agro-healing survey. Wanju, Korea: Rural Development Administration.

Gim, G.M., J. Moon, S.J. Jeong, and S.M. Lee. 2013. Analysis on the present status and characteristics of agro-healing in Korea. J. Agric. Ext. Community Dev. 20(4):909-936.

Her, S.Y. and H.J. Hong. 2013. A study about the effect of reading enhancement and the selfrespect improvement of children through an animal assisted therapy. J. Korean Biblia Soc. Libr. Inf. Sci. 24(3):181-198.

DOI:10.14699/kbiblia.2013.24.3.181

Hine, R., J. Peacock, and J. Pretty. 2008. Care farming in the UK: Evidence and opportunities. Report for the National Care Farming Initiative (NCFI). Colchester, U.K.: University of Essex.

Jeong, N. and D. Ahn. 2015a. Analysis of the physiological healing effects by forest types: Focused on hypertensive and diabetic. J. Korean Inst. Landsc. Archit. 43(5):1-12. DOI:10.9715/KILA.2015.43.5.001

Jeong, N. and D. Ahn. 2015b. Analysis of image and healing perception effect according to the forest types. J. East Asian Landsc. Stud. 9(1):85-93.

Jeong, N. and D. Ahn. 2016. Analysis of the psychological relaxation effects of different forest types and user. J. Korean Soc. People Plants Environ. 19(2):121-128. DOI:10.11628/ksppe.2016.19.2.121

Jeong, S.J. 2017. Study on methodology and evaluation system of care farming. Wanju, Korea: Rural Development Administration. 
Jung, H.S. 2015. Effects on the children's emotion of single-parent family by the group art therapy using animal-assisted activities. Master's thesis, Wonkwang University, Iksan, Korea.

Kang, D.K. and H. Kim. 2017. College students' acceptance of therapeutic agricultural activities and occupational intention about therapeutic agricultural professional. Rural Soc. 27(1):125-173. Retrieved from http://www.krss.or.kr

Kawate, T. 2015. Status and support policy of welfare agriculture in Japan. Proceedings of Korea Urban Agriculture Research International Symposium on Agro Healing and Sixth industrialization of Rural Tourism (pp. 67-84). Chuncheon, Korea: Korea Urban Agriculture Research Association. Retrieved from http://iarr.kangwon.ac.kr/NFUpload/ nfupload_down.php?tmp_name $=20150609160348.5490 .3 .1 \&$ name $=\% \mathrm{EC} \% \mathrm{~B} 9 \% \mathrm{~B} 4 \% \mathrm{EC} \% 99 \% 80 \% \mathrm{ED} \% 85 \% 8 \mathrm{C}+\%$ ED\%86\%A0\%ЕC\%BF\%A0\%EC\%95\%BC+\%ЕA\%B5\%90\%ЕC\%88\%98(\%ЕC\%9D\%BC\%ЕB\%B3\%B8\%ЕВ\%8C $\% 80 \%$ ED\%95\%99).pdf

Kim, E.A. 2017. The effects of horticulture therapy on overcoming depression through improvement of emotional stability and self-esteem of juvenile prisoners. J. Korean Soc. Flor. Art Des. 37:49-67.

Kim, O.J. 2013. Animal-assisted therapy for ADHD children. J. Korean Vet. Med. Assoc. 49(2):112-115.

Kim, O.J. and K.S. Ha. 2018. A study on the variables affecting the intention to use healing agriculture. Asia Pac. J. Bus. Ventur. Entrep. 13(4):59-72.

Kwak, D.S. 2015. A study on service design for revitalizing welfare horticulture programs - Focusing on G Social Welfare Center's horticulture programs for the single elderly -. J. Korean Soc. Des. Cult. 21(4):21-31.

Lee, J.H., H.J. Kim, S.M. Lee, A.K. Lee, and J.K. Suh. 2009. An analysis of horticultural activities on journal of cure and rehabilitative division for horticultural therapy. J. Korean Soc. People Plants Environ. 12(3):25-30.

Lee, S.M., G.M. Gim, S.H. Jeong, and Y.J. Kim. 2016. Agro-healing service case report. Wanju, Korea: Rural Development Administration.

Lee, S.W. 2013. International survey of green care in agriculture and development of strategy in domestic. Wanju, Korea: Rural Development Administration.

Loue, S. 2016. Therapeutic farms: Recovery from mental illness. Springer.

Park, A.S. 2014. The study on the trends of cooking therapy in Korea: With the study on the theses from 2000 to 2013. Master's thesis, Nambu University, Kwangju, Korea.

Park, H. and D.K. Kang. 2017. Suggestions for applications of therapeutic farms for promoting school community engagement in Korea based on review of therapeutic farms, gardens, animals, policies, and laws in the U.S.A. Rural Soc. 27(2):215-269. Retrieved from http://www.krss.or.kr

Park, H.J. and C.H. Kim. 2012. The effects of an animal-assisted therapy (AAT) program on depression and self-esteem of adolescents as victims of school violence. Korean J. Vet. Serv. 35(4):327-332.

Sempik, J., R. Hine, and D. Wilcox (Eds.). 2010. Green Care: A conceptual framework. A report of working group in health benefits of green care (COST 866, Green care in agriculture). Loughborough, U.K.: Centre for child and family research, Loughborough University. 